\title{
Representation and Integration of New Political Issues in Party Systems:
}

\author{
Analyses of New Challenger Parties in 15 West European Democracies
}

Airo Hino*

abstract: Advanced democracies have witnessed new types of political issues being represented and integrated in their party systems in the past decades. Yet, their patterns still remain unknown as to the conditions in which new political issues are first represented and eventually integrated in each party system. To fill this gap, this article illustrates such patterns through different phases of socio-economic transformation, party system responses to newly emerging issues, and electoral systems' openness. By applying a 'doublehurdle' model, the article tries to elucidate the mechanisms in which new political issues are represented in the first hurdle and then integrated in party systems in the second hurdle. The analyses of new challenger parties across 15 West European democracies revealed that New Politics issues are represented through New Politics Parties (NPPs) when existing party systems are not responsive to the new issues but NPPs further grow and New Politics issues are integrated in party systems when existing party systems are more $r e$ sponsive to these newly emerging issues. Likewise, different conditions mattered differently for the representation and growth hurdles for both NPPs and Extreme Right Parties (ERPs).

Key Words: New Challenger Parties, new political issues, double-hurdle model, political opportunity structure

\section{Introduction}

Advanced democracies constantly experience change and persistence of her

* Waseda Univercity, Faculty of Political Science and Economics, Professer, Electoral Studies Comparative Politics 
party system and scholars have long paid attention to its causal patterns and consequences. One of the causes of party system change is a transformation of cleavage structures (Lipset and Rokkan, 1967) and changes in a line of conflicts with regard to value systems (Inglehart, 1977; 1990; Flanagan, 1987). To name but a few examples in the history of West European democracies, the Industrial Revolution led to the formation of labour and social democratic parties; and the arrival of 'affluent society' (Galbraith, 1958) and its subsequent penetration of 'post-materialist' or 'left-libertarian' values gave rise to a formation of green and New Politics parties (Müller-Rommel, 1985b; Poguntke, 1987). The impacts of these waves of socio-economic transformation are certainly present in each of the countries, yet the patterns in which it appears are diverse. It is these patterns that this article puts particular focus on. How would a newly emerging political issue be represented in each party system? Subsequently, how would a new political issue be integrated in each party system? These phases of representation and integration of new political issues could be reasonably different but such mechanisms are not sufficiently elucidated in the literature. With this motivation, this article aims to provide a set of patterns in which new political issues affect party systems and to examine what factors promote or hinder their representation and integration. To this end, the article analyses the development of new challenger parties in 15 West European democracies over the decades. Below the article first describes main patterns in which new political issues could be represented and/or integrated in a party system. After discussing which cases, variables and models to be employed in an overall research design, it will then present the findings from the analyses of new challenger parties, in particular, New Politics Parties (NPPs) and Extreme Right Parties (ERPs) in Western Europe. It will conclude with some discussions over the findings.

\section{Patterns of Representation and Integration of New Political Issues}

The ways in which new political issues are represented and/or integrated in a party system are determined in the sequences of the following four phases. 
Figure 1 Patterns of Representation and Integration of New Political Issues

Phase 0

SOCIO-ECONOMIC

Social Transformation
Phase 1

INFORMAL POS

Party System (t1)
Phase 2

FORMAL POS

Electoral System

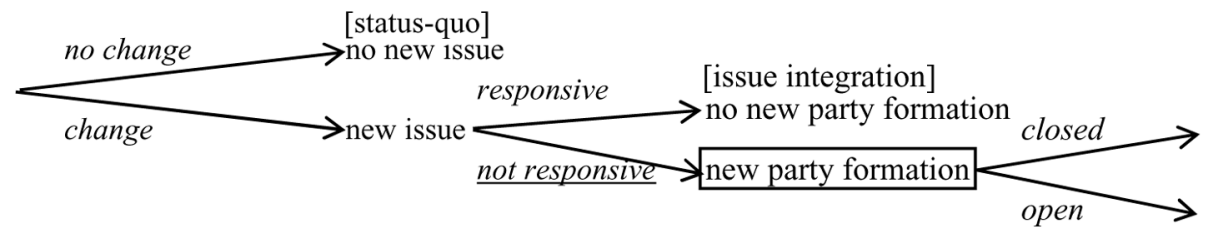

Figure 1 illustrates the four phases and how new issues (do not) end up being represented and/or integrated.

In Phase 0, new political issues need to arise with a socio-economic transformation, or if not, issue dimensions remain as a status-quo. It is labelled Phase 0 since this is a phase rooted in a socio-economic domain, which is prerequisite for representation and integration of new political issues. Although these social-economic transformations are operationalised empirically later to control for their variations, new political issues are treated as given from this point onwards in theorising their patterns of representation and integration in party systems.

Phase 1 to Phase 3 constitute political and institutional domains and, in other words, Political Opportunity Structure (POS) of new parties. Political Opportunity Structure is different from the socio-economic domain of Phase 0 in that it is the domain related to 'institutions' in general. In more concrete, these institutions range from informal institutions related to party systems to formal institutions related to electoral systems.

In Phase 1, existing party systems, an informal component of POS, play a role in facilitating or not facilitating new party formation. If existing parties are responsive to newly emerging issues, then there is no need for new parties to be formed. New interests articulated in the form of movements and/or interest groups remain as such and would not result in a formation of new political 


\section{Phase 3 \\ INFORMAL POS \\ Party System (t2)}

[no issue representation] no new party representation new party representation

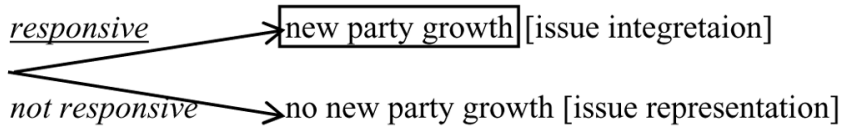

party. Contrarily, if existing parties are not responsive to new issues, a political party is more likely to be formed to convey new voices and demands of society. Let us call this phase Party System ( $t 1)$.

In Phase 2, electoral systems, a formal component of POS, play a role in determining whether or not new parties are represented in parliament. If electoral systems are closed to new entrants, newly formed parties would not have a chance to be represented. This would lead to 'no new party representation' in Figure 1. If electoral systems are open to new political forces which tend to be small in size, new parties earn legislative representation. In which case, new issues will be represented in parliament.

In Phase 3, existing party systems, an informal POS, once again play a role in encouraging or not encouraging a further growth of new parties. Unlike in Phase 1, party systems are expected this time to assist a further growth of new parties if they are responsive to the new issues already represented. Once the existing parties understand the importance of new issues, it would help new parties in garnering more votes, and eventually more seats in parliament. In this scenario, new issues are well integrated in its party system. On the contrary, if existing parties do not react to the entry of new parties in parliament, new parties would not gain a momentum to further grow. In this scenario, new issues are represented but not well integrated in its party system. Let us call this phase Party Systems ( $t 2)$. 
Each phase will be discussed in more detail in the sections below.

\section{1 Phase 0: Socio-economic Transformation}

One may put socio-economic transformation as the 'push' factor, while the POS of Phase 1 to Phase 3 as a 'pull' factor of new parties' development (Rüdig, 1990). Socio-economic transformation can be mainly summarised in the following four aspects: i) the arrival of 'affluent society'; ii) the post-war consensus on the welfare state; iii) the globalisation of the economy coupled with the increasing circulation of goods and people; and iv) the development of a multi-cultural society.

It has been widely argued that post-war economic prosperity has given rise to the evolution of 'New Politics' parties (Inglehart, 1977, 1990; Dalton et al., 1984; Müller-Rommel, 1985a, 1993; Poguntke, 1987, 1993). The theory of value change maintains that post-materialist value orientations have diffused in western democracies during the post-war decades, and that this wave of generational 'value change' leads to various social movements such as student, environmental, feminist, and anti-war movements (Inglehart, 1977, 1990, 1997). The eruption of new social movements has led to the formation of new parties, often referred to as Greens (Rüdig, 1985), ecology parties (Müller-Rommel, 1982), left-libertarian parties (Kitschelt, 1988), and 'New Politics' parties (Poguntke, 1987).

It has also been suggested that modern welfare states have been a source of general discontent among western publics. Full-fledged welfare states have produced 'more regulated and less democratic civil societies' (Redding and Viterna, 1999: 495), and new social movements often criticise the domination of bureaucracy in the public arena. Modern welfare states generated the social thrust underlying 'New Politics' parties, but on the other hand produced a source of public discontent on which extreme right parties capitalise. Extreme right parties have attacked neo-corporatist management of the political economy; and generous welfare benefits for immigrants are often the object of their criticism. Examples abound of the success of extreme right parties, such as the Austrian Freedom Party in 1999 that campaigned against Austrian neo- 
corporatism.

The intensification of globalisation may also be part of the radical socio-economic transformation. Some claim that extreme right parties (or radical rightwing populist parties) are invigorated by the acceleration of globalisation (Swank and Betz, 2003). Voters for extreme right parties tend to be predominantly small shopkeepers, farmers, semi- and unskilled workers, who are vulnerable in the increasing competition of a global economy (Kriesi, 1999). The increasing globalisation entails a further circulation of goods and people, which often endangers the life of marginalised workers.

The deepening of multi-cultural societies may also have contributed to the eruption of new political parties. Many have argued that increasing numbers of immigrants have given rise to xenophobic and anti-immigrant sentiments among publics, around which extreme right parties have mobilised (e.g. Swyngedouw et al., 1997; Lubbers et al., 2002; Golder, 2003; Lucassen and Lubbers, 2012). The growing diversity of contemporary societies may have, on the other hand, mobilised support for 'New Politics' parties that subscribe to human rights and libertarian principles (Poguntke, 1989). Some scholars have developed a model of a 'new politics dimension' in which 'New Politics' parties and extreme right parties represent the New Left pole of libertarianism and the New Right pole of authoritarianism respectively (Flanagan, 1987; Inglehart and Minkenberg, 1989; Ignazi, 1992, 1997; Swyngedouw, 1994; Kitschelt, 1995). In this context, this article examines both 'New Politics' parties and extreme right parties to understand the nature of socio-economic transformation.

\section{2 Phase 1: Party Systems $(t 1)$}

Party systems are expected to play an important role in determining how new political issues are represented and/or eventually integrated. New issues are politicised as a result of new demands arising in society. This can be understood as an 'input' process in political system (Easton, 1965). In such a situation, political parties have two options. One is to take a responsive approach to new demands in taking up the new issues in their policies and representing the concerns in society, thereby integrating the new issues into the existing 
party systems. The other is to take a non-responsive approach to the newly emerging issues, thereby not representing the new concerns in the party system. In the former scenario, new parties would not be formed as the new issues are already taken up in the existing system, whereas in the latter scenario, new parties would be formed to convey new messages in society through the electoral process.

Whether party systems take a responsive or a non-responsive approach would depend on various factors including types of new demands and patterns of party competitions. If new issues are related to the increasing presence of immigrants in society and welfare services to be given to them, existing parties that are part of neo-corporatist management of welfare states would be inclined to defending the existing system of universalistic welfare provisions. In turn, existing parties may find it easier to take in concerns over environmental protection. Similarly, it would be more difficult for parties to adopt new issues in a centripetal party system as the competition is mainly centred on bread and butter issues, while it would be easier in a centrifugal party system to address new issues since there are more policy flexibility and fluidity.

\section{3 Phase 2: Electoral Systems}

Electoral systems play a crucial role in determining whether new parties are to be represented or not. When electoral systems are more open, new political issues are represented through the representation of new parties in the legislative arena. When electoral systems are more closed, new political issues are not represented. Whether issues are to be integrated in party systems depends on the responsiveness of existing party systems at the subsequent phase. As discussed more extensively below for the double-hurdle model, the openness of electoral systems could affect the fate of new party representation and the degree of their further growth differently.

Electoral systems here refer to institutional constraints and facilitators that new parties have in the electoral process. This includes not only the electoral systems per se but also conditions in which public party funding is available to new challenger parties. The details of the variables are further discussed 
below.

\section{4 Phase 3: Party Systems ( $t 2)$}

Party systems are expected to play yet again an important role in determining whether new political issues would be integrated in the system. Contrary to Phase 1, existing parties now face new parties represented in legislature. If party systems are responsive to the new political issues that new parties address, they would be eventually integrated in the system. If party systems are non-responsive to the new political issues, they would not be integrated but represented in the system.

The fate of new political parties differs according to the responsiveness of existing parties on new issue domains. If existing parties are responsive and address new political issues, it would help new parties to earn 'issue ownership' on the new issues and eventually help them grow further. In contrast, if existing parties are non-responsive and ignore the new political issues, new parties would not gain a salience of the issues of their ownership and struggle in growing further. This theoretical prediction is partly in line with Meguid (2005: 350) in that adversarial strategies of mainstream parties could potentially increase niche party electoral support. But it differs from Meguid (2005) in that accommodative strategies of main stream parties does not decrease their electoral support but further strengthen the electoral appeal of new parties.

\section{Research Design}

\section{1 Case Selection}

To examine the effects of socio-economic, party systems, and electoral systems conditions, cases in this article are selected based on the Most Similar Systems Design (MSSD) (Przeworski and Teune, 1970; Pennings et al., 1999; Landman, 2000; 2003). In an MSSD study, one can control for the basic features of cases of comparison while analysing the key features that vary across them. This research strategy is particularly pertinent to a comparative study 
based on a single area such as Europe and Latin America (Przeworski and Teune, 1970: 33; Landman, 2000: 28), since the conditions of similar systems are largely met from the outset.

The fifteen countries analysed in this article are thus Austria, Belgium, Denmark, Finland, France, Germany, Iceland, Ireland, Italy, Luxembourg, Netherlands, Norway, Sweden, Switzerland, and United Kingdom. These countries are homogeneous in that they all have 1) established and long-term democracies; 2) advanced industrial economies with GDP per capita of more than 20,000 US dollars; and 3) Christianity-based cultures with a predominantly Christian population 1. By holding constant the basic country characteristics that are 'mostly' similar, this design would allow us to examine the socio-economic conditions and POS in more direct terms.

New challenger parties are defined as new parties that attempt to enter the party system to stress the importance of new issues such as environmental protection and immigration control (Hino, 2012). New Politics Parties (NPPs) and Extreme Right Parties (ERPs) are often regarded as challenger parties of new left and new right respectively that distinguish themselves from the existing parties. These two types of new challenger parties are selected in this article based on their programmatic profile mainly available from their manifestos using the Comparative Manifesto Project (CMP)2. The parties se-

Table 1 List of New Politics Parties (NPPs) and Extreme Right Parties (ERPs) in the study

\begin{tabular}{cll}
\hline \multicolumn{1}{c}{ Country } & \multicolumn{1}{c}{ NPPs } & \multicolumn{1}{c}{ ERPs } \\
\hline Austria & $\begin{array}{l}\text { Green Alternative } \\
\text { (Die Grüne Alternative) }\end{array}$ & $\begin{array}{l}\text { Austrian Freedom Party } \\
\text { (Freiheitliche Partei Österreichs) }\end{array}$ \\
\hline Belgium & $\begin{array}{l}\text { Agalev [Live Differently] } \\
\text { (Anders Gaan Leven) }\end{array}$ & $\begin{array}{l}\text { Flemish Bloc (Vlaams Blok) } \\
\text { National Front (Front National) }\end{array}$ \\
& $\begin{array}{l}\text { Ecolo (Ecologistes confédérés pour } \\
\text { l'organisation de luttes originales) }\end{array}$ & \\
\hline Denmark & Socialist People's Party & Progress Party \\
& (SocialistiskFolkeparti) & (Fremskridtspartiet) \\
& Common Course (Fælles Kurs) & $\begin{array}{l}\text { Danish People's Party } \\
\text { (Densk Folkeparti) }\end{array}$ \\
& Red-Green Unity List & \\
\hline Finland & De Rød-Grønne) & True Finns (Perussuomalaiset) \\
& Democratic Alternative & Young Finns \\
& (Demokraattinen Vaihtoehtoe) & (Nuorsuomalainen Puolue) \\
\hline
\end{tabular}


Table 1 List of New Politics Parties (NPPs) and Extreme Right Parties (ERPs) in the study, more

\begin{tabular}{cll}
\hline \multicolumn{1}{c}{ Country } & \multicolumn{1}{c}{ NPPs } & \multicolumn{1}{c}{ ERPs } \\
\hline France & The Greens (Les Verts) & National Front (Front National) \\
& Ecology Generation & \\
& (Génération Écologie) & \\
\hline Germany & The Greens (Die Grüne), & National Democratic Party of Germany \\
& renamed to Alliance 90/Greens & (Nationaldemokratische Partei Deutsch- \\
& (Bündnis 90/Die Grüne) in 1993 & lands) \\
& & German People's Union \\
& (Deutsche Volksunion) \\
& & The Republicans (Die Republikaner) \\
\hline
\end{tabular}

\begin{tabular}{|c|c|c|}
\hline Iceland & $\begin{array}{l}\text { Women's Alliance (Kvennalisti) } \\
\text { Left-Green Movement } \\
\text { (Vinstrihreyfingin - Græntframbod) }\end{array}$ & \\
\hline Ireland & Green Party & Progressive Democrats \\
\hline Italy & $\begin{array}{l}\text { Green Federation } \\
\text { (Federazione dei Verdi) }\end{array}$ & $\begin{array}{l}\text { Italian Social Movement } \\
\text { (Movimento Sociale Italiano) } \\
\text { The Northern League (Lega Nord) }\end{array}$ \\
\hline Luxembourg & $\begin{array}{l}\text { Green Alternative } \\
\text { (Di Grëng Alternativ) } \\
\text { Green List Ecological Initiative } \\
\text { (Greng Lëscht Ekologesch Initiativ) }\end{array}$ & \\
\hline Netherlands & $\begin{array}{l}\text { Democrats } 66 \text { (Democraten 66) } \\
\text { Radical Political Party } \\
\text { (Politieke Partij Radikalen) } \\
\text { Green Left (GroenLinks) }\end{array}$ & $\begin{array}{l}\text { Centre Party (Centrumpartij), renamed } \\
\text { to Centre Party '86 (Centrumpartij '86) } \\
\text { in } 1986 \\
\text { Centre Democrats (Centrumdemocraten) }\end{array}$ \\
\hline Norway & $\begin{array}{l}\text { Socialist People's Party } \\
\text { (Sosialistisk Folkeparti), } \\
\text { renamed to Socialist Left Party } \\
\text { (Sosialistisk Venstreparti) in } 1975 \\
\text { New People's Party } \\
\text { (Det Nye Folkepartiet) }\end{array}$ & $\begin{array}{l}\text { Anders Lange's Party } \\
\text { (Anders LangesParti), } \\
\text { renamed to Progress Party } \\
\text { (Fremskrittspartiet) in } 1977\end{array}$ \\
\hline Sweden & $\begin{array}{l}\text { Green Ecology Party } \\
\text { (Miljöpartiet de Gröna) }\end{array}$ & $\begin{array}{l}\text { Sweden Democrats } \\
\text { (Sverigedemokraterna) } \\
\text { New Democracy (Ny Demokrati) }\end{array}$ \\
\hline Switzerland & $\begin{array}{l}\text { Greens (Grüne), renamed to Federation } \\
\text { of Green Parties (Fédération Suisse des } \\
\text { Partis Écologistes) in 1983, } \\
\text { and to Green Party of Switzerland } \\
\text { (Grüne Partei der Schweiz / Parti Écolo- } \\
\text { giste Suisse) in } 1987\end{array}$ & $\begin{array}{l}\text { National Action against Foreign Domina- } \\
\text { tion (Nationale Aktion gegen die Über- } \\
\text { fremdung von Volk und Heimat / Action } \\
\text { Nationale contre l'Emprise et la Surpopu- } \\
\text { lation Etrangère), renamed to National } \\
\text { Action for People and Fatherland (Nation- } \\
\text { ale Aktion für Volk und Heimat / Action } \\
\text { Nationale pour le Peuple et la Patrie) in } \\
\text { 1979, and to Swiss Democrats } \\
\text { (Schweizer Demokraten / Démocrates } \\
\text { Suisses) in 1991 } \\
\text { Swiss Motorists' Party (Schweizer Auto } \\
\text { Partei / Parti Automobiliste Suisse), re- } \\
\text { named to Freedom Party of Switzerland } \\
\text { (Freiheitspartei de Schweiz) in 1994 }\end{array}$ \\
\hline UK & Green Party & $\begin{array}{l}\text { National Front } \\
\text { British National Party }\end{array}$ \\
\hline
\end{tabular}


lected for each of NPPs and ERPs are shown in Table 1.

\section{2 Operationalisation}

As illustrated in Figure 1, formations of new challenger parties and their further growth are determined by socio-economic, party systems, and electoral systems conditions. Since the nature of variables differs between NPPs and ERPs, operationalisation of variables is detailed below separately.

\section{2. 1 New Politics Parties (NPPs)}

For NPPs, the conditions comprise of three socio-economic variables (labelled $S$ ), two party systems (informal POS) variables (labelled $P$ ), and three electoral systems (formal POS) variables (labelled 1).

The details of operationalisation and data source are as follows 3 .

\section{S1: GDP per capita}

Inglehart $(1977,1990)$ has argued that younger generations in advanced industrial countries, or affluent societies, tend to subscribe to 'postmaterialist' values that emphasise the needs of 'self-actualisation', namely intellectual and aesthetic needs. The hypothesis linking economic growth and the rise of a New Politics agenda has been tested in previous studies by using income per capita (Kitschelt, 1988), growth rate of GDP (Müller-Rommel, 1998), and GDP per capita (Redding and Viterna, 1999). All of these studies, but to varying degrees, support the hypothesis. Thus, in line with existing studies, we expect that higher economic growth promotes the emergence of NPPs, which, in turn, contributes to their growth. The measure of affluence is GDP per capita from the Penn World Table 6.1, which represents real GDP per capita in US dollars at current prices (Heston et al., 2002) ${ }^{4}$.

\section{S2: Urbanisation}

Urbanisation is an important element in Inglehart's theorisation, with the process of urbanisation bringing lifestyle issues and environmental protection on to the political agenda (Inglehart, 1977; 1990). This variable on urbanisation 
measures the percentage of dwellers in urban centres among the population in each country (Easterly and Sewadeh, 2005), and is employed to capture the socio-structural transformation.

\section{S3: Government expenditure}

In Kitschelt (1988) and Redding and Viterna (1999), government social security expenditure is discussed as an important factor in the development of new social movements and NPPs. Comprehensive welfare states, as Redding and Viterna (1999: 495) argue, have produced 'the more regulated and less democratic civil societies', and new social movements tend to criticise the domination of bureaucracy in the public arena. Kitschelt (1988) treats this variable as a part of the Political Opportunity Structure, while Redding and Viterna (1999) theorise it as a factor on the 'demand' side (socio-economic conditions). This study takes the latter approach and identifies it as one of the socio-economic conditions. This variable on government expenditure represents the total current disbursements for general government, including central, state, and local government, as a percentage of GDP5.

\section{P1: Policy space of New Politics issues}

The hypothesis on 'policy space' forms an integral part of the 'informal' POS. If existing parties were already covering the issues that new political forces wish to address, there would be little political opportunity for new challenger parties to introduce their policy innovations into the electoral market. This idea of 'policy space' or 'policy niche' has been noted in several studies (Hauss and Rayside, 1978; Müller-Rommel, 1982; Harmel, 1985; Rüdig, 1992) and presented in the most formalised form by Hug (1996; 2001), yet there has been little attempt to test the claim comparatively except for some studies (e.g. Meguid, 2005; 2008)6. This study measures the policy distance between the NPPs and other parties with regard to the New Politics agenda referring to a set of policy items available from the Comparative Manifestos Project (CMP) dataset7. The policy space variable is expected to have an impact on the emergence of NPPs but in the opposite way on their success. Since other parties 
can be expected to react to the emergence of NPPs, attempting to incorporate the new issues to close the gap, the policy distance would be narrowed after the breakthrough of NPPs into a party system. Once existing parties follow the NPPs, it would then strengthen their chance of increasing their support and securing more seats in parliament.

\section{P2: Party system convergence (divergence)}

This hypothesis derives from the classical theory of Downs (1957) that parties converge to the middle of the political spectrum as a result of electoral competition to secure the so-called 'median voter' (Budge et al., 1987; Budge, 1994). Party system convergence opens a space on both extremes of the political spectrum. Under such circumstances, as the mainstream party of the right and the left moves to a centrist position, NPPs have a political opportunity to mobilise in the space to the left, attracting votes from those dissatisfied or disaffected with the conventional parties. To construct the index, the study employs the CMP data (Budge et al., 2001). For each election in each country, an index score is computed by taking a standard deviation (a square root of variance statistic) of parties' scores on the left-right scale of the CMP data (i.e. 'rile' index). The left-right position of each party is given a weighting according to its party size by multiplying each party's vote share for each election by its score on the left-right scale8.

\section{I1: Threshold}

The threshold to secure a seat is determined by district magnitude and legal threshold if applicable. The general rule is that the bigger the size of the electoral district is, in other words, the lower the electoral threshold is, the easier it is to be represented, and the more proportional the system becomes (Taagepera and Shugart, 1989; Lijphart, 1994). To quantify the threshold, the study applies the measurement of 'effective magnitude' or 'effective threshold'. Taagepera and Shugart (1989) measured the 'effective magnitude' $\left(\mathrm{M}^{\prime}\right)$ by the formula: $M^{\prime}=\frac{50 \%}{T}$, where $\mathrm{T}$ is the 'average threshold'. Similarly, Lijphart (1994) formulated the 'effective threshold' $\left(\mathrm{T}^{\prime}\right): T^{\prime}=\frac{50 \%}{M+1}+\frac{50 \%}{2 M}$, 
if $M>1$; where $M$ is the 'average magnitude', the upper threshold $\frac{50 \%}{M+1}$ represents the threshold of exclusion, and the lower threshold $\frac{50 \%}{2 M}$ reflects the threshold of inclusion (representation). Despite some differences, both formulae are designed to convert district magnitude or threshold into an effective value 9 . Thus, in this study, the formula adopted for 'effective threshold' is: $T^{\prime}=\frac{75 \%}{M+1}$, where $\mathrm{M}$ is the average district magnitude (Lijphart, 1994: 183; 1999: 153; Taagepera, 1998: 394). In case of two-tier systems, decisive tiers set out by Lijphart (1994: 30-39) and Carter (2002: 129-31) are taken. This study follows the approach taken by Lijphart (1994) to place a higher value between 'effective threshold' and 'legal threshold'. For the sources of this variable, see Hino (2012).

\section{I2: Electoral formulae}

The literature suggests that there is a general consensus over which formula is more proportional than others. The various formulae in PR systems include the Hare quota, the Droop quota, and the Imperiali quota in the largest remainder systems, as well as the d'Hondt divisor method, the Sainte-Laguë divisor method, and the modified Sainte-Laguë divisor method in the highest average systems (Farrell, 2001: 71-79). Lijphart (1994: 24, 153-159) suggests that these formulae can be classified in the following order of proportionality: the Hare quota and the Sainte-Laguë divisor method are the most proportional formula; the Droop quota, the modified Sainte-Lague divisor method, and the single transferable vote system are less proportional; and the d'Hondt divisor method and the Imperiali quota are the least proportional of all. Although Lijphart's decision to include the single transferable vote system in this list has been contested, the general order of listing matches with the existing literature (Rae, 1967; Loosemore and Hanby, 1971; Lijphart, 1986). To operationalise the proportionality of electoral formulae, this study classified them into the following groups in accordance with Lijphart's (1994: 159) 'proportionality' ordering: $0=$ majority/plurality (First Passed The Post); 1 = d'Hondt/Imperiali; 2 = modified Saint-Laguë/Droop/Single Transferable Vote; 3 = Hare/Pure Saint-Laguë. See Hino (2012) for the sources. 


\section{I3: Public party funding}

Financial resources are particularly important for new challenger parties; they determine the organisational survival and electoral success of parties (Rüdig, 1992: 187). Arguably, the rise of 'cartel party' (Katz and Mair, 1995) and the diffusion of public funding schemes could undermine the development of new parties; for example, by public funds being allocated to existing parties. Yet, some scholars argue that public party funding favours the development of new parties. Pierre et al. (2000: 16), analysing the impact of state subsidies, conclude that 'subsidies frequently play a fundamental role in the consolidation of new parties'10. Public party funding was operationalised in two steps. First, the study established whether or not such public funding is available. Second, it classified the criteria for obtaining state finance. The criteria vary across countries from equal allocation to all parties (equal basis), proportional allocation by a percentage of total votes in the previous election (vote basis), or a percentage of parliamentary seats (seat basis). For new challenger parties, the 'equal basis' would be the most favourable; the proportional allocation on a 'vote basis' the next most favourable; and proportional allocation on a 'seat basis' would be the less favourable. A new challenger party that failed to win seats might still attract public funds proportional to its vote share. No public financing is the least favourable setting for new challenger parties since they often lack financial resource at their launching stage. Hence, the variable is scaled as follows: $0=$ 'no public finance'; 1 = 'proportional allocation'; 2 = 'equal allocation'. The data sources for this variable are detailed in Hino (2012).

\section{2. 2 Extreme Right Parties (ERPs)}

For ERPs, three electoral systems (formal POS) variables (labelled I) are identical. Here three socio-economic variables (labelled $S$ ) are described in depth as they are set out differently from NPPs. Two party systems (informal POS) variables (labelled $P$ ) are also briefly discussed in the context of the rise of ERPs. 
S1: Foreigners

The existing research suggests that ERP voters generally regard immigration as one of the key issues in deciding which party to vote for (Mitra, 1988; Mayer and Perrineau, 1992; Swyngedouw et al., 1997: 12; Kessler and Freeman, 2004). Hence, it is logical to assume that ERPs are more successful in polities where the foreign population is more numerous (Golder, 2003: 440441). This study used the percentage of foreign population to cover the whole time series ${ }^{11}$.

S2: Unemployment

It has been suggested that higher rates of unemployment provide a favourable electoral ground for ERPs (Jackman and Volpert, 1996). Equally, in individuallevel data analyses, there is plenty of evidence suggesting that unemployed people are more likely to support ERPs (Baimbridge, et al., 1995; Lubbers $e t$ al., 2002: 362-363). However, there is disagreement in the extant literature about the mechanisms at work. Knigge (1998: 266) found the adverse effect of unemployment on right-wing support and concluded that 'unemployment apparently dampens macro-level support for extreme right-wing parties.' This counter-intuitive finding is echoed in later studies, which find a negative relationship between the aggregate unemployment rate and ERP votes (Lubbers et al., 2002: 364-367; Kessler and Freeman, 2004: 17) or report no significantly positive link between the two (Swank and Betz, 2003: 232). The data used here derive from the official unemployment statistics compiled by Eurostat.

\section{S3: Taxation}

Some scholars have stressed the neo-liberal trend in the policy programmes of ERPs. Kitschelt (1995) sheds important light on the anti-statist orientation of what he coins the 'New Radical Right' (NRR) and argues that the NRR is on the rise along with anti-statist and anti-establishment feelings among Western publics. This is exemplified in the Progress Party's success in the 1973 'earthquake' election in Denmark. High taxation is one key condition for the anti-statist appeal as the call for greater efficiency as well as less bureaucracy in a 
country's governance is often linked with tax issues. Swank and Betz (2003) tested this 'tax backlash' hypothesis and found a stable relationship with the electoral success of ERPs. Likewise, this study includes taxation by measuring the total tax revenue as percentage of GDP provided by OECD.

\section{P1: Policy space of New Right issues}

If the issues promoted by ERPs are already addressed by other parties, ERPs have no business to launch a party and strive to win votes; if the issues are not covered by other parties, ERPs have the comparative advantage in the electoral market. The role of existing parties on the electoral fortunes of ERPs has been most rigorously examined in recent research (e.g. Meguid, 2005; Ivarsflaten, 2008)12. To test the hypothesis, this study sets up a 'policy space' variable from the CMP data measuring the policy gap between ERPs and all other parties. A composite New Right Index is constructed based on neo-conservative and neo-liberal issues available from the CMP data (see Appendix Table A2). The distance between the score of the ERPs and all other parties on the New Right Index is measured by subtracting the average score of all other parties from the ERP score.

\section{P2: Party system convergence (divergence)}

The variable of party system convergence is identical to the one constructed for the NPPs. Here the contexts in the analyses for ERPs are given. Kitschelt (1995: 20-21) builds on this Downsian perspective to posit the hypothesis that 'NRR [New Radical Right] parties are most likely to appear and to be electorally successful ... in circumstances where there has been a convergence between the main moderate left and right conventional parties'. While the hypothesis is widely disseminated, there have been limited attempts to test its validity cross-nationally. One exception is Abedi (2002) who tested the hypothesis in a systematic and cross-national manner. Abedi (2002: 554-555) criticises Kitschelt on two methodological points: the data used were only a single point in time (i.e. 1990) and only two major parties were used for calculating the 'divergence' score. To overcome these limitations, this study con- 
structed an index of 'Party System Divergence' based on the left-right positions of all parties contesting an election. In addition, whereas Abedi (2002) uses expert surveys conducted at different time points (e.g. Dodd, 1976; Castles and Mair, 1984; Huber and Inglehart, 1995), this study uses the original manifestos data derived from the CMP.

\section{3 Double-hurdle models}

As discussed above in Figure 1, existing party systems are expected to play a different role in the process of representing new political issues and in the process of integrating them. In other words, existing parties may well affect the emergence phase of new challenger parties and their growth phase in a distinct manner. The importance of distinguishing the emergence of new parties and their success has been theoretically discussed (Harmel, 1985; Harmel and Robertson, 1985: 502-7; Hug, 2000: 188; Hug, 2001: 65-70). This point is well illustrated by Harmel and Robertson (1985: 502) in stating that ' $[t]$ he distinction between the two dependent variables [new party formation and new party success] is particularly important for theoretical purposes because it cannot be assumed that the same conditions that encourage new party formation will necessarily provide those new parties with success; it also cannot be assumed that the lack of facilitators necessary for electoral success will inhibit the initial formation of new parties'. Yet, there has been little empirical research to model these two different dependent variables ${ }^{13}$.

To model the differential effects of socio-economic, party systems, and electoral systems conditions, this study applies a 'double-hurdle model' (Jones, 1989). The 'double-hurdle model' or often referred to as 'Cragg's model' (Cragg, 1971) was developed to capture whether or not one would purchase certain goods (e.g. cigarette) and how much one would purchase once one decided to purchase them. In other words, the model encompasses the binary choice of goods consumption and the extent to which such goods are consumed. This model can be applied to studying new political issues that new challenger parties aim to focus on. The first 'hurdle' for new challenger parties is to gain seats in parliament (thus new political issues are represent- 
ed), whereas the second 'hurdle' is to increase their seat share (thus new issues are integrated).

The model assumes the following two distributions: i) a binary distribution to depict the existence of new challenger parties (Probit equation); and ii) a truncated distribution to capture the distribution of the vote/seat share among the new challenger parties (truncated regression equation). The two equations enable us to capture these differential logics: the probit equation analyses the conditions of new challenger parties' presence (i.e. the emergence process), and the truncated regression equation analyses the conditions of their performance variations (i.e. the success process).

The double-hurdle model relaxes the Tobit restriction of a latent variable and applies a more general model by employing a decomposing technique ${ }^{14}$. The decomposed model is summarised in two equations (Lin and Schmidt, 1984: 174):

$$
\begin{aligned}
& \mathrm{P}\left(y_{t}=0\right)=\Phi\left(-X_{t} \beta_{1}\right) \\
& f\left(y_{t} \mid y_{t}>0\right)=\frac{1}{\Phi\left(X_{t} \beta_{2} / \sigma\right)} \frac{1}{\sqrt{2 \pi} \sigma} \times \exp \left\{\frac{-1}{2 \sigma^{2}}\left(y_{t}-X_{t} \beta_{2}\right)^{2}\right\}
\end{aligned}
$$

These two equations are based on the models developed by Cragg (1971: 831). The first equation captures the probit model and depicts the probability of a zero observation with parameter vector $\beta_{1}$, where $y_{t}$ is the dependent variable, $X_{t}$ is a row vector of $\mathrm{K}$ explanatory variables, and the notation $\Phi($.) denotes the standard normal cumulative distribution function. The second equation, in turn, captures the truncated regression model and depicts the value of the dependent variable $y_{t}$ of a non-limit (i.e. positive) observation, where the density of $y_{t}$ is $\mathrm{N}\left(X_{t} \beta_{2}, \sigma^{2}\right)$, truncated at zero. The virtue of the double-hurdle model lies in its approach to estimate limit observations and non-limit observations separately and independently. If the two processes are estimated in one equation (e.g. the Tobit model), the differential mechanisms at work for the emergence and success processes remain concealed.

Whether or not to apply the Tobit model or the decomposed model is also an empirical question. The applicability of the decomposed model against To- 
bit model can be empirically tested by the Lagrange multiplier test (Lin and Schmidt, 1984: 175-6) or the likelihood ratio test (Greene, 2003: 770). This study applies the latter likelihood ratio test, which can be easily applied by computing:

$$
\lambda=-2\left[\ln L_{T}-\left(\ln L_{P}+\ln L_{T R}\right)\right]
$$

where $L_{T}$ is the likelihood for the tobit model with the same coefficients, $L_{P}$ is the likelihood for the probit model with separate coefficients, and $L_{T R}$ is the likelihood for the truncated regression model with separate coefficients. The results of the test indicate whether or not the decision to model the emergence and success of new parties separately is valid against the restrictive Tobit model. In using the likelihood ratio test, the analyses below follow the application in the literature (e.g. Liu and Reilly, 1999, Burke et al., 2003).

\section{Analyses}

Table 2 and Table 3 report the results of the analyses for the NPPs and ERPs respectively ${ }^{15}$. In both analyses, the double-hurdle model is a valid model against Tobit model according to the likelihood ratio test reported in the footnotes of the tables, demonstrating that socio-economic conditions and the POS conditions (i.e. party systems and electoral systems conditions) differently determine the chances of emergence and success of NPPs and ERPs.

Among others, the most interesting finding is that "P1: Policy space of New Politics issues" is positively significant in the probit model but negatively significant in the truncated regression model for the analyses of NPPs in Table 216. This means that when there is a policy gap between NPPs and existing parties, NPPs are more likely to emerge. Yet, NPPs are more likely to further succeed when the policy gap decreases. In other words, when existing parties are not responsive to New Politics issues, NPPs are likely to secure their seats in parliament, but in contrast when existing parties are more responsive, NPPs are likely to further increase their seat share.

At first sight, this finding may seem paradoxical, but was theoretically 
Table 2 Double-hurdle Model of NPPs: Representation and Integration of New Politics issues

\begin{tabular}{|c|c|c|c|}
\hline \multirow[t]{2}{*}{ Dependent Variable: Seat share of NPPs } & \multirow{2}{*}{$\begin{array}{c}\text { Tobit } \\
\text { Model }\end{array}$} & \multicolumn{2}{|c|}{ Double-hurdle Model } \\
\hline & & Probit & $\begin{array}{l}\text { Truncated } \\
\text { Regression }\end{array}$ \\
\hline \multirow[t]{2}{*}{ S1: GDP per Capita } & $0.00030^{* *}$ & $0.00009^{*}$ & $0.00024^{*}$ \\
\hline & $(0.00011)$ & $(0.00004)$ & $(0.00012)$ \\
\hline \multirow[t]{2}{*}{ S2: Urbanisation } & $0.18012^{* *}$ & $0.07247^{* * *}$ & 0.07948 \\
\hline & $(0.03001)$ & $(0.02008)$ & $(0.05896)$ \\
\hline \multirow[t]{2}{*}{ S3: Government Expenditure } & $0.11004 \dagger$ & 0.01729 & -0.05629 \\
\hline & $(0.06020)$ & $(0.01679)$ & $(0.07339)$ \\
\hline \multirow[t]{2}{*}{ P1: Policy space of New Politics issues } & $0.08399^{*}$ & $0.12636^{* *}$ & $-0.11618^{*}$ \\
\hline & $(0.03449)$ & $(0.04701)$ & $(0.05512)$ \\
\hline \multirow[t]{2}{*}{ P2: Party system divergence } & 0.05943 & -0.00689 & 0.41160 \\
\hline & $(0.19150)$ & $(0.04156)$ & $(0.28854)$ \\
\hline \multirow[t]{2}{*}{ I1: Threshold } & $-0.22333 \dagger$ & -0.01936 & $-0.78407^{* *}$ \\
\hline & $(0.13534)$ & $(0.02462)$ & $(0.26150)$ \\
\hline \multirow[t]{2}{*}{ I2: Electoral formulae } & $2.40107^{*}$ & $1.27934^{* *}$ & 0.82126 \\
\hline & $(1.20391)$ & $(0.49519)$ & $(0.79983)$ \\
\hline \multirow[t]{2}{*}{ I3: Public party funding } & 1.02002 & 0.36003 & 1.02648 \\
\hline & (1.47703) & $(0.32856)$ & $(1.26200)$ \\
\hline \multirow[t]{2}{*}{ Constant } & $-23.62171^{* * *}$ & $-9.50544^{* *}$ & 0.16268 \\
\hline & $(2.77812)$ & $(2.62871)$ & (8.07085) \\
\hline Observations & 149 & 149 & 76 \\
\hline
\end{tabular}

expected. As discussed above in Figure 1, when existing parties are not responsive to new issues in Phase 1, new parties are expected to emerge. Once new parties made their inroads into legislatures, they are expected to further grow when existing parties are in turn responsive to the new issues in Phase 3. The more existing parties try to catch up with new challenger parties by covering new issues, the more effective it becomes for new challenger parties to address their issues. At this stage, new challenger parties already possess 'issue ownership' and can capitalise on the increasing salience of their issues. Further attentions to the new issues would validate the credentials of new challengers.

A typical example can be found in the Belgian greens, Agalev (Dutch-speaking) and Ecolo (French-speaking). Being the first greens in the world to seize representation at national level in 1981, they had a competitive edge on New 
Table 3 Double-hurdle Model of ERPs: Representation and NonIntegration of New Right issues

\begin{tabular}{lccc}
\hline Dependent Variable: Seat share of ERPs & Tobit & \multicolumn{2}{c}{ Double-hurdle Model } \\
\cline { 3 - 4 } & Model & Probit & $\begin{array}{c}\text { Truncated } \\
\text { Regression }\end{array}$ \\
\hline S1: Foreigners & 0.57300 & $0.30637^{* *}$ & 0.02799 \\
S2: Unemployment & $(0.39385)$ & $(0.09859)$ & $(0.29864)$ \\
& 0.66658 & $0.45538^{* *}$ & 0.06214 \\
S3: Taxation & $(0.43662)$ & $(0.13696)$ & $(0.41345)$ \\
& -0.03865 & -0.05939 & $-0.45168^{*}$ \\
P1: Policy space of New Right issues & $(0.17571)$ & $(0.05969)$ & $(0.20801)$ \\
& 0.22336 & $0.12584^{* *}$ & 0.06429 \\
P2: Party system divergence & $(0.00000)$ & $(0.03833)$ & $(0.04351)$ \\
& $-1.75018^{* *}$ & $-0.56550^{*}$ & -0.98335 \\
I1: Threshold & $(0.66000)$ & $(0.23672)$ & $(0.94414)$ \\
& -0.20102 & $-0.12970^{* *}$ & -0.60990 \\
I2: Electoral formulae & $(0.17388)$ & $(0.05029)$ & $(0.38079)$ \\
& $6.47653^{* *}$ & $1.41374^{*}$ & $8.73607^{* *}$ \\
I3: Public party funding & $(1.69109)$ & $(0.65135)$ & $(2.39280)$ \\
& $4.38859^{*}$ & 1.21184 & $7.87202^{* *}$ \\
Constant & $(2.00288)$ & $(0.84742)$ & $(2.65277)$ \\
Observations & -12.27742 & -2.51793 & 6.00262 \\
& $(12.20746)$ & $(2.02187)$ & $(9.10889)$ \\
\hline
\end{tabular}

Robust standard errors (clustered by countries) in parentheses. $* * \mathrm{p}<0.01, * \mathrm{p}<0.05$

Likelihood Ratio test of the double-hurdle model: $56.71>20.09(\mathrm{df}=8 ; \mathrm{p}<0.01)$.

Politics issues against the existing parties, i.e. Christian democrats, liberals, socialists, and regionalists. The policy gap of New Politics issues was in fact 3.05 percent in the CMP data. In the next election in 1985, the existing parties closed the gap by addressing 15.57 percent of the whole manifestos on New Politics issues, which was in fact one percent more than the average of Agalev and Ecolo. Yet the results were a further growth of these two parties; Agalev doubled its seats from 4 seats and Ecolo grew from 2 to 5 seats.

A contrast is noteworthy in Table 3 for the effects of " $P 1$ : Policy space of New Right issues". ERPs indeed tend to emerge when the New Rights issues are not addressed by the existing parties as was the case with NPPs. However, ERPs do not grow when existing parties address the New Right issues after their appearance. Contrarily, they are more likely to increase their seat share when existing parties ignore the new issues and ERPs have a wider pol- 
icy gap against the other parties. Even though the effect is not statistically significant, the coefficient for the truncated regression analysis is positive. Note that this was negatively significant for NPPs in Table 2 .

Table 2 and Table 3 both show that socio-economic conditions and electoral systems conditions also matter for the development of new challenger parties. As discussed in Figure 1, social transformation paves the way for the birth of new parties in Phase 0. Economic growth and urbanisation are conducive to the emergence of NPPs, while increases in foreign population and unemployment foster the arrival of ERPs. Equally, electoral institutions play an important role as expected in Phase 2 of Figure 1. Electoral formulae are responsible for the representation of both NPPs and ERPs, while effective threshold promotes legislative appearance of EPRs and further growth of NPPs. Public party funding as part of electoral institutions favours further growths of ERPs.

\section{Conclusion}

This article attempted to analyse the topic of 'representation' and 'integration' in light of new political issues: under what conditions new political issues are represented and integrated in party systems. To this end, it first set out patterns in which new political issues can arise from social transformation and then can be channelled through the checkpoints of POS, ranging from informal ones of policy competition and to formal ones of electoral institutions. To test the effects of socio-economic, party systems, and electoral systems conditions on the two stages of parties' development, the 'double-hurdle' model was applied, which allows us to examine the effects separately.

The results mostly lent support to the theoretical expectation of all three domains of socio-economic conditions, and party systems and electoral systems conditions, which constitute the POS. Given that each domain appeared to be relevant in the development of new challenger parties, they are not sufficient but necessary to facilitate the rise of the new challenger parties. Yet for the representation and integration of new issues, existing parties play a crucial role in determining the formation of new challenger parties and also their 
further growth. If existing parties are already responsive to new issues in Phase 1, new parties would not be formed but new issues are already on its way to be integrated in party systems. In other words, policy renewal of existing parties is sufficient for integrating new kinds of political issues once social transformation makes it relevant for existing parties to take measures.

The main finding of this article among others was that the role of existing parties could differ for the first and second hurdles of the model. In the first hurdle, existing parties could facilitate the rise of new challenger parties by not being responsive to new issues. On the contrary, existing parties could in turn encourage, despite their will, a further growth of new challenger parties by trying to catch up with the new issues. Once new challenger parties succeed in establishing their 'issue ownership', they may well take advantage of this differential effect of policy gaps and build up their presence by letting other parties address 'their issue'.

One caveat with this though is that this differential effect only applied to NPPs not to ERPs. One possibility is that the different nature of New Politics issues and New Right issues may have affected the ways in which existing parties reacted to the emerging issues. Given that the New Politics issues tend to be 'valence' and 'consensus' types of issues such as environmental protection and promotion of democracy, existing parties could have easily adopted these new demands in society and incorporate into their policy packages. Whereas in the case of the New Right issues which stress the importance of traditional morality, law and order, and national way of life, existing parties could occasionally refrain from addressing these issues. The 'positional' nature of the New Right issues could have conditioned the ways in which existing parties (did not) react to the new issues brought attention to by ERPs.

The contrasting results between NPPs and ERPs could shed light on varying scenarios in which 'issue ownership' works for new challenger parties and how issues can be further integrated. If the issues are of consensus type, new challenger parties could be better off if existing parties follow their path. Once new challenger parties establish their issue ownership, they could manage to have their policy integrated into the whole party system by highlighting its 
salience. If the issues are of positional type, new challenger parties could be better off if existing parties neglect the new issues as they could stand in the electoral market as the only seller of such issues. In this perspective, it is reasonable to understand that some of extreme right and right-wing populist leaders choose the anti-establishment rhetoric and strategically distance themselves from the existing parties. It could be thus that new challenger parties are adopting their strategies according to the types of issues they are trying to address.

(1) Greece, Spain, and Portugal are not included due to the timing of their democratisation during the 1970s. Liechtenstein, Monaco, and San Marino are also excluded as they are mini-states (population less than 50,000).

(2) NPPs are mainly selected based on New Politics Index constructed with the CMP data and ERPs are primarily selected based on New Right Index based on the CMP data. For the construction of both indices, please see Appendix Table A1 and A2. For further discussions, see Hino (2012: 13-52).

(3) The descriptions of each variable derive from Hino (2012).

(4) Since the Penn World Table 6.1 lacks data for the 1960s in Germany, those data are supplemented by OECD National Accounts.

(5) The index consists of 'final consumption expenditure, subsidies, property income payable, current taxes on income and wealth payable, social benefits other than social transfers in kind and other current transfers' (OECD, 2001: 74).

(6) Another valuable exception is Lubbers et al. (2002), although their focus is on the development of extremeright parties in Western Europe. Lubbers and his collaborators calculated the 'policy space' based on an expert survey that located extreme right parties according to their stance on immigration issue. They calculated the difference between the score of extreme right parties on immigration and the score of a party with the next highest score on the issue.

(7) The New Politics Index (NPI) constructed from the CMP data is shown in Appendix Table A1.

(8) This approach is taken by Sigelman and Nam Yough (1978) in constructing the polarisation measure in the United States as well as by Dorussen and Nanou (2006) for measuring divergence in European party systems.

(9) Initially, both formulae suffered from an overestimation of thresholds in the 
case of $M=1$. When $M=1$ (i.e. in single-member district systems), the formulae produce the threshold of 50 per cent while, in reality, candidates in singlemember districts could win with less than 50 per cent of votes. To correct for this problem, Lijphart (1994: 182-3, fn.29; 1999: 153) and Taagepera (1998) put forward the form of $T^{\prime}=\frac{25 \%(3 M+1)}{M(M+1)}$, which with simplifying assumptions is transformed to: $T^{\prime}=\frac{75 \%}{M+1}$. This formula captures the thresholds of plurality systems (i.e. $M=1$ ) more accurately (37.5 per cent instead of 50 per cent in the previous formulae).

(10) Kitschelt (2000: 174) seems to be of a similar view: 'State funding does not protect established parties from new party challenges'. In fact, Katz and Mair (1995) themselves speculated about the possibilities of right-wing populist parties benefiting from being excluded from the cartels (Katz and Mair, 1995: 23-5; Mair, 1997: 117-9).

(11) For the foreign population data, I used the variable complied by Golder (2003), which is mainly based on the OECD-SOPEMI data.

(12) Lubbers et al. (2002) tested the 'policy space' or 'policy niche' hypothesis based on an expert survey that located ERPs according to their stance on immigration. Arzheimer and Carter (2006) also tested the hypothesis by examining the policy positions of the major party of the mainstream right using the CMP data. Neither obtained the expected results: Lubbers et al. found no significant effect of the policy gap on immigration; Arzheimer and Carter found a positive effect of the policy position of the mainstream right party, suggesting that the narrower the gap the better the electoral performance of ERPs.

(13) Hug (2001: 79-123) built on this differentiation of the dependent variables by employing the number of new parties to analyse the emergence of new parties and their vote share for their further success. Instead of employing the number of new parties, this study considers emergence as a binary category of the existence of new parties and aims to integrate the analyses of both emergence and success.

(14) The description of the double-hurdle model derives from Hino (2012: 6365).

(15) Standard errors are robustly calculated using the Huber-White sandwich estimator of variances and adjusted by clustering on each country to account for heterogeneity. Fixed effect models are not used as the estimates are bound to be inconsistent due to 'incidental parameter problem' (Neyman and Scott, $1948)$ for the limited dependent variables. See Hino $(2010 ; 2012)$ for further discussions. 
(16) The models including the lagged seat share as a control variable are shown in Appendix Table A3. "P1: Policy space of New Politics issues" is no longer statistically significant for truncated regression but remains negative $(\mathrm{p}=.138)$. Other approaches in controlling for time dependence have been taken by including time fixed effects (for each five year periods given that a national election is held at least once in five years). See Hino (2012) for the discussions in dealing with the time-series.

\section{References}

Abedi, Amir. 2002. 'Challenges to established parties: The effects of party system features on the electoral fortunes of anti-political-establishment parties'. European Journal of Political Research, 41(4): 551-583.

Arzheimer, Kai, and Carter, Elisabeth. 2003. 'Political opportunity structures and right-wing extremist party success'. European Journal of Political Research, 45(3): 419-443.

Baimbridge, Mark, Burkitt, Brian and Macey, Mary. 1995. 'The European Parliamentary election of 1994 and racism in Europe'. Ethnic and Racial Studies, 18(1): 128-130.

Budge, Ian, Robertson, David, and Hearl, Derek J. 1987. Ideology, Strategy and Party Change: Spatial Analyses of Post-War Election Programmes in 19 Democracies. Cambridge: Cambridge University Press.

Budge, Ian. 1994. 'A new spatial theory of party competition: Uncertainty, ideology and policy equilibria viewed comparatively and spatially'. British Journal of Political Science, 24(4): 443-467.

Budge, Ian, Klingemann, Hans-Dieter, Volkens, Andrea, Bara, Judith, and Tanenbaum, Eric (eds.). 2001. Mapping Policy Preferences: Estimates for Parties, Electors, and Governments 1945 - 1998. Oxford: Oxford University Press.

Burke, Andrew E., FitzRoy, Felix R., and Nolan, Michael A. 2003. Beyond the 'employee or entrepreneur' dichotomy: Accounting for entrepreneurial persistence and type'. The Centre for Small and Medium Sized Enterprises, Warwick Business School, Working Paper No. 81.

Carter, Elisabeth. 2002. 'Proportional representation and the fortunes of rightwing extremist parties'. West European Politics, 25(3): 125-146.

Castles, Francis G. and Mair, Peter. 1984. 'Left-right political scales: Some 'expert' judgements'. European Journal of Political Research, 12(1): 73-88.

Cragg, John G. 1971. 'Some statistical models for limited dependent variable with application to durable goods.' Econometrica, 39(5): 829-844. 
Dalton, Russell J., Flanagan, Scot. C., and Beck, Paul. A. (eds.). 1984. Electoral Change in Advanced Industrial Democracies: Realignment or Dealighment? Princeton: Princeton University Press.

Dodd, Lawrence C. 1976. Coalitions in Parliamentary Government. Princeton: Princeton University Press.

Dorussen, Han and Nanou, Kyriaki. 2006. 'European integration, intergovernmental bargaining, and convergence of party programmes'. European Union Politics, 7(2): 235-256.

Downs, Anthony. 1957. An Economic Theory of Democracy. New York: Harper.

Easterly and Sewadeh. 2005. Global Development Finance and World Development Indicators, cited in the Macro Time Series Dataset of the Global Development Network Growth Database (compiled by William Easterly and Mirvat Sewadeh in the World Bank Group: http://econ.worldbank.org/WBSITE/EXTER NAL/EXTDEC/EXTRESEARCH/0,,contentMDK:20701055 pagePK:6421482 5 piPK:64214943 theSitePK:469382,00.html; accessed 7 November, 2015). Easton, David. 1965. A Framework for Political Analysis. New York: PrenticeHall.

Farrell, David. 2001. Electoral Systems: A Comparative Introduction. New York: Palgrave.

Flanagan, Scott, C. 1987. 'Value change in industrial societies'. American Political Science Review, 81(4): 1303-1319.

Galbraith, John Kenneth. 1958. The Affluent Society. London: Hamish Hamilton.

Golder, Matt. 2003. 'Electoral institutions, unemployment and extreme right parties: A correction'. British Journal of Political Science, 33(3): 525-34.

Greene, William H. 2003. Econometric Analysis. 5th edition. Upper Saddle River, NJ: Prentice Hall.

Harmel, Robert. 1985. 'On the study of new parties'. International Political Science Review 6(4): 401-418.

Harmel, Robert, and Robertson, John D. 1985. 'Formation and success of new parties: A cross-national analysis'. International Political Science Review, 6(4): 501-23.

Hauss, Charles, and Rayside, David. 1978. 'The development of new parties in western democracies since 1945', pp.31-57 in: Maisel, Louis and Cooper, Joseph. (eds.) Political Parties: Development and Decay. Beverly Hills: Sage Publication.

Heston, Alan, Summers, Robert, and Aten, Bettina. 2002. Penn World Table Version 6.1, Center for International Comparisons, University of Pennsylvania 
(CICUP).

Hino, Airo. 2012. New Challenger Parties in Western Europe: A Comparative Analysis. London: Routledge.

Huber, Jon, and Inglehart, Ronald. 1995. 'Expert interpretations of party space and party locations in 42 societies'. Party Politics, 1(1): 73-111.

Hug, Simon. 1996. 'The emergence of new political parties from a game theoretic perspective'. European Journal of Political Research, 29(2): 169-190.

Hug, Simon. 2000. 'Studying the electoral success of new political parties: A methodological note'. Party Politics, 6(2): 187-197.

Hug, Simon. 2001. Altering Party Systems: Strategic Behavior and The Emergence of New Political Parties in Western Democracies. Ann Arbor: University of Michigan Press.

Ignazi, Piero. 1992. 'The silent counter-revolution: Hypotheses on the emergence of extreme right-wing parties in Europe'. European Journal of Political Research, 22(1): 3-34.

Ignazi, Piero. 1997. 'New challenges: Post-materialism and the extreme right', pp.300-324 in: Rhodes, Martin, Heywood, Paul, and Wright, Vincent (eds.), Developments in West European Politics. New York: St. Martin's Press.

Inglehart, Ronald. 1977. The Silent Revolution. Princeton: Princeton University Press.

Inglehart, Ronald. 1990. Culture Shift in Advanced Industrial Society. Princeton: Princeton University Press.

Inglehart, Ronald, 1997, Modernization and Postmodernization: Cultural, Economic, and Political Change in 43 Societies. Princeton: Princeton University Press.

Inglehart, Ronald, and Minkenberg, Michael. 1989. 'Neoconservatism and value change in the USA: Tendencies in the mass public of a postindustrial society', pp.81-109 in: Gibbins, John R. (ed.), Contemporary Political Culture. London: Sage Publications.

Ivarsflaten, Elisabeth. 2008. 'Populists in power: Attitudes toward immigrants after the Austrian Freedom Party entered government', pp.175-188 in: Deschouwer, Kris (ed.), New Parties in Government: In Power for the First Time. London: Routledge.

Jackman, Robert, and Volpert, Karin. 1996. 'Conditions favouring parties of the extreme right in Western Europe'. British Journal of Political Science, 26(4): 501-521.

Jackman, Robert, and Volpert, Karin. 1996. 'Conditions favouring parties of the 
extreme right in Western Europe'. British Journal of Political Science, 26(4): 501-521.

Jones, Andrew M. 1989. ‘A double-hurdle model of cigarette consumption'. Journal of Applied Econometrics, 4: 23-39.

Katz, Richard, and Mair, Peter. 1995. 'Changing models of party organization and party democracy: The emergence of the cartel party'. Party Politics, 1: 5-28.

Kessler, Alan, E., and Freeman, Gary, P. 2004. 'Political opportunism, social exclusion, and support for right-wing extremist parties in Western Europe'. Paper presented at the 2004 Annual Meeting of the American Political Science Association, Chicago, 2-5 September.

Kitschelt, Herbert. 1988. 'Left-libertarian parties: Explaining innovation in competitive party systems'. World Politics, 40(2): 194-234.

Kitschelt, Herbert. 1995. The Radical Right in Western Europe. Ann Arbor: University of Michigan Press.

Kitschelt, Herbert. 2000. 'Citizens, politicians, and party cartellization: Political representation and state failure in post-industrial democracies. European Journal of Political Research, 37(2): 149-179.

Knigge, Pia. 1998. 'The ecological correlates of right-wing extremism in Western Europe'. European Journal of Political Research, 34(2): 249-279.

Kriesi, Hanspeter. 1999. 'Movements of the left, movements of the right: Putting the mobilization of the two types of social movements into context', pp. 398-423 in: Kitschelt, Herbert, Lange, Peter, Marks, Gary, and Stephens, John (eds.), Continuity and Change in Contemporary Capitalism. Cambridge: Cambridge University Press.

Landman, Todd. 2000. Issues and Methods in Comparative Politics: An Introduction. London: Routledge.

Landman, Todd. 2003. Issues and Methods in Comparative Politics: An Introduction. $2^{\text {nd }}$ edition. London: Routledge.

Lijphart, Arend. 1986. 'Degrees of proportionality of proportional representation formulas', pp.170-179 in: Grofman, Bernard, and Lijphart, Arend (eds.), Electoral Laws and their Political Consequences. New York: Agathon Press.

Lijphart, Arend. 1994. Electoral Systems and Party Systems: A Study of TwentySeven Democracies, 1945-1990. Oxford: Oxford University Press.

Lin, Tsai-Fen, and Schmidt, Peter. 1984. 'A test of the tobit specification against an alternative suggested by Cragg'. The Review of Economics and Statistics, 66(1): 174-177.

Lipset, Seymour M. and Rokkan, Stein. 1967. 'Cleavage structures, party sys- 
tems, and voter alignments: An introduction', pp.1-64 in: Lipset, Seymour M. and Rokkan, Stein (eds.), Party Systems and Voter Alignments. New York: The Free Press.

Liu, Qiming, and Reilly, Barry. 1999. 'The private income transfers of Chinese rural migrants: Some empirical evidence from Jinan'. Working paper. The Poverty Research Unit. University of Sussex.

Loosemore, John, and Hanby, Victor J. 1971. 'The theoretical limits of maximum distortion: Some analytic expressions for electoral systems'. British Journal of Political Science, 1(4): 467-477.

Lubbers, Marcel, Gijsberts, Mérove, and Scheepers, Peer. 2002. 'Extreme rightwing voting in Western Europe'. European Journal of Political Research, 41(3): 345-378.

Lucassen, Geertje, and Lubbers, Marcel. 2012. 'Who fears what?: Explaining farright-wing preference in Europe by distinguishing perceived cultural and economic ethnic threats'. Comparative Political Studies, 45(5): 547-574.

Mair, Peter. 1997. Party System Change: Approaches and Interpretations. Oxford: Oxford University Press.

Mayer, Nonna, and Perrineau, Pascal. 1992. 'Why do they vote for Le Pen?'. European Journal of Political Research, 22(1): 123-141.

Meguid, Bonnie M. 2005. 'Competition between unequals: The role of mainstream party strategy in niche party success'. American Political Science Review, 99(3): 347-359.

Meguid, Bonnie M. 2008. Party Competition between Unequals: Strategies and Electoral Fortunes in Western Europe. Cambridge University Press.

Mitra, Subrata. 1988. 'The National Front in France: A single-issue movement?'. West European Politics, 11(2): 47-64.

Müller-Rommel, Ferdinand. 1982. 'Ecology parties in Western Europe'. West European Politics, 5(1): 68-74.

Müller-Rommel, Ferdinand. 1985a. 'New social movements and smaller parties: A comparative perspective'. West European Politics, 8(1): 41-54.

Müller-Rommel, Ferdinand. 1985b. 'The greens in western Europe: Similar but different'. International Political Science Review, 6(4): 483-499.

Müller-Rommel, Ferdinand. 1993. Grüne Parteien in Westeuropa: Entwicklungsphasen und Erforgsbedingungen. Opladen: WestdeutcherVerlag.

Müller-Rommel, Ferdinand. 1998. 'Explaining the electoral success of green parties: A cross-national analysis'. Environmental Politics, 7(4): 145-154.

Neyman, Jerzy, and Scott, Elizabeth. 1948. 'Consistent estimates based on par- 
tially consistent observations'. Econometrica, 16(1): 1-32.

OECD. 2001. Historical Statistics 1970-2000. Paris: OECD.

Pennings, Paul, Keman, Hans, and Kleinnijenhuis, Jan. 1999. Doing Research in Political Science: An Introduction to Comparative Methods and Statistics. London: Sage Publications.

Pierre, Jon, Svåsand, Lars, and Widfeldt, Anders. 2000. 'State subsidies to political parties: Confronting rhetoric with reality'. West European Politics, 23(3): 124.

Poguntke, Thomas. 1987. 'New politics and party systems: The emergence of a new type of party?'. West European Politics, 10(1): 76-88.

Poguntke, Thomas. 1989. 'The "new politics dimension” in European green parties', pp.175-194 in: Müller-Rommel, Ferdinand (ed.), New Politics in Western Europe: The Rise and Success of Green Parties and Alternative Lists. Boulder: Westview Press.

Poguntke, Thomas. 1993. Alternative Politics: The German Green Party. Edinburgh: Edinburgh University Press.

Przeworski, Adam, and Teune, Henry. 1970. The Logic of Comparative Social Inquiry. New York: Wiley Interscience.

Rae, Douglas. 1967. The Political Consequences of Electoral Laws. New Haven: Yale University Press.

Redding, Kent and Viterna, Jocelyn S. 1999. 'Political demands, political opportunities: Explaining the differential success of Left-Libertarian parties'. Social Forces, 78(2): 491-510.

Rüdig, Wolfgang. 1985. 'The greens in Europe: Ecological parties and the European Elections of 1984'. Parliamentary Affairs, 38(1): 56-72.

Rüdig, Wolfgang. 1990. Explaining Green Party Development: Reflection on a Theoretical Framework. Glasgow: Strathclyde Papers on Government and Politics.

Rüdig, Wolfgang. 1992. 'Comparing green parties', pp.185-198 in: Rüdig, Wolfgang (ed.), Green Politics Two. Edinburgh: Edinburgh University Press.

Sigelman, Lee and Nam Yough, Syng. 1978. 'Left right polarization in national party systems: A cross-national analysis'. Comparative Political Studies, 11(3): 355-379.

Swank, Duane, and Betz, Hans-Georg. 2003. 'Globalization, the welfare state and right-wing populistm in Western Europe'. Socio-Economic Review, 1(2): 215245.

Swyngedouw, Marc. 1994. 'New cleavages in Flemish-Belgian politics: Testing theoretical models'. ISPO Bulletin, 1994/13. Leuven: University of Leuven. 
Swyngedouw, Marc, Beerten, Roeland, et Billiet, Jaak. 1997. 'Les motivations électorales en Flandre 21 mai 1995'. CRISP Courrier Hebdomadaire, n. 1557. Bruxelles: Centre de Recherche et d'Information Socio-Politiques.

Taagapera, Rein and Shugart, Mathew S. 1989. Seats and Votes: The Effects and Determinants of Electoral Systems. New Haven: Yale University Press.

Appendix Table A1: Composition of the New Politics Index (NPI)

\begin{tabular}{lll}
\hline $\begin{array}{l}\text { Programmatic } \\
\text { Themes }\end{array}$ & Policy items & Description \\
\hline $\begin{array}{l}\text { Environmentalism } \\
\text { / Ecologism }\end{array}$ & $\begin{array}{l}\text { Environmental } \\
\text { Protection } \\
\text { (per 501) }\end{array}$ & $\begin{array}{l}\text { Preservation of countryside, forests, etc.; general preser- } \\
\text { vation of natural resources against selfish interests; } \\
\text { proper use of national parks; soil banks, etc; environ- } \\
\text { mental improvement. }\end{array}$ \\
\cline { 2 - 3 } & $\begin{array}{l}\text { Anti-Growth } \\
\text { Economy } \\
\text { (per 416) }\end{array}$ & $\begin{array}{l}\text { Favourable mentions of anti-growth politics and steady } \\
\text { state economy; ecologism; "Green politics"; sustainable } \\
\text { development. }\end{array}$ \\
\hline Libertarianism & $\begin{array}{l}\text { Democracy } \\
\text { (per 202) }\end{array}$ & $\begin{array}{l}\text { Favourable mentions of democracy as a method or goal in } \\
\text { national and other organisations; involvement of all citi- } \\
\text { zens in decision-making, as well as generalised support } \\
\text { for the manifesto country's democracy }\end{array}$ \\
\hline Multiculturalism & $\begin{array}{l}\text { Multiculturalism: } \\
\text { Positive } \\
\text { (per 607) }\end{array}$ & $\begin{array}{l}\text { Cultural diversity, communalism, cultural plurality and pil- } \\
\text { larization; preservation of autonomy of religious, linguis- } \\
\text { tic heritages within the country including special } \\
\text { educational provisions. }\end{array}$ \\
\cline { 2 - 3 } & $\begin{array}{l}\text { Underprivileged } \\
\text { Minority Groups } \\
\text { (per 705) }\end{array}$ & $\begin{array}{l}\text { Favourable references to underprivileged minorities who } \\
\text { are defined neither in economic nor in demographic } \\
\text { terms, e.g. the handicapped, disabled, homosexuals, immi- } \\
\text { grants, refugees etc. }\end{array}$ \\
\hline $\begin{array}{l}\text { Military: Negative } \\
\text { (per 105) }\end{array}$ & $\begin{array}{l}\text { Favourable mentions of decreasing military expenditures; } \\
\text { disarmament; 'evils of war'; promises to reduce conscrip- } \\
\text { tion }\end{array}$ \\
\cline { 2 - 4 } & $\begin{array}{l}\text { Peace } \\
\text { (per 106) }\end{array}$ & $\begin{array}{l}\text { Peace as a general goal; declarations of belief in peace and } \\
\text { peaceful means of solving crises; desirability of countries } \\
\text { joining in negotiations with hostile countries }\end{array}$ \\
\cline { 2 - 4 } & $\begin{array}{l}\text { Internationalism: } \\
\text { Positive } \\
\text { (per 107) }\end{array}$ & $\begin{array}{l}\text { Need for international co-operation; need for aid to devel- } \\
\text { oping countries; need for world planning of resources; } \\
\text { need for international courts; support for any interna- } \\
\text { tional goal or world state; support for Un }\end{array}$ \\
\hline
\end{tabular}

Note: Each variable (issue category) represents the emphasis given to the item in the manifesto, expressed as a percentage of all sentences in the manifestos. For discussions on programmatic themes, see Hino (2012: 14-17). Source: Budge et al. (2001: Appendix 3). 
Appendix Table A2: Composition of the New Right Index (NRI)

\begin{tabular}{|c|c|c|}
\hline $\begin{array}{l}\text { Programmatic } \\
\text { themes }\end{array}$ & Policy items & Description \\
\hline \multirow[t]{4}{*}{ Neo-conservatism } & $\begin{array}{l}\text { Traditional } \\
\text { Morality: Positive } \\
\text { (per 603) }\end{array}$ & $\begin{array}{l}\text { Favourable mentions of traditional moral values; prohibi- } \\
\text { tion, censorship and suppression of immorality and un- } \\
\text { seemly behaviour; maintenance and stability of family; } \\
\text { religion. }\end{array}$ \\
\hline & $\begin{array}{l}\text { Law and Order } \\
\text { (per 605) }\end{array}$ & $\begin{array}{l}\text { Enforcement of all laws; actions against crime; support } \\
\text { and resources for police; tougher attitudes in courts. }\end{array}$ \\
\hline & $\begin{array}{l}\text { National Way of } \\
\text { Life: Positive } \\
\text { (per 601) }\end{array}$ & $\begin{array}{l}\text { Appeals to patriotism and/or nationalism; suspension of } \\
\text { some freedoms in order to protect the state against sub- } \\
\text { version; support for established national ideas. }\end{array}$ \\
\hline & $\begin{array}{l}\text { Military: Positive } \\
\text { (per 104) }\end{array}$ & $\begin{array}{l}\text { Need to maintain or increase military expenditure; mod- } \\
\text { ernising armed forces and improvement in military } \\
\text { strength; rearmament and self-defence; need to keep mili- } \\
\text { tary treaty obligations; need to secure adequate man- } \\
\text { power in the military. }\end{array}$ \\
\hline \multirow[t]{4}{*}{ Neo-liberalism } & $\begin{array}{l}\text { Free Enterprise } \\
\text { (per 104) }\end{array}$ & $\begin{array}{l}\text { Favourable mentions of free enterprise capitalism; superi- } \\
\text { ority of individual enterprise over state and control sys- } \\
\text { tems; favourable mentions of private property rights, } \\
\text { personal enterprise and initiative; need for unhampered } \\
\text { individual enterprises. }\end{array}$ \\
\hline & $\begin{array}{l}\text { Incentives } \\
\text { (per 402) }\end{array}$ & $\begin{array}{l}\text { Need for wage and tax policies to induce enterprise; en- } \\
\text { couragement to start enterprise; need for financial and } \\
\text { other incentives such as subsidies. }\end{array}$ \\
\hline & $\begin{array}{l}\text { Economic } \\
\text { Orthodoxy } \\
\text { (per 414) }\end{array}$ & $\begin{array}{l}\text { Need for traditional economic orthodoxy, e.g. reduction of } \\
\text { budget deficits, retrenchment in crisis, thrift and savings; } \\
\text { support for traditional economic institutions such as stock } \\
\text { market and banking system; support for strong currency. }\end{array}$ \\
\hline & $\begin{array}{l}\text { Governmental } \\
\text { and Administra- } \\
\text { tive Efficiency } \\
\text { (per 303) }\end{array}$ & $\begin{array}{l}\text { Need for efficiency and economy in government and ad- } \\
\text { ministration; cutting down civil service; improving gov- } \\
\text { ernmental procedures; general appeal to make the } \\
\text { process of government and administration cheaper and } \\
\text { more effective. }\end{array}$ \\
\hline
\end{tabular}

Note: Each variable (issue category) represents the emphasis given to the item in the manifesto, expressed as a percentage of all sentences in the manifestos. For discussions on programmatic themes, see Hino (2012: 34-38). Source: Budge et al. (2001: Appendix 3). 
Appendix Table A3: Double-hurdle Model of NPPs (with a lagged seat share): Representation and Integration of New Politics issues

\begin{tabular}{lccc}
\hline Dependent Variable: Seat share of NPPs & Tobit & \multicolumn{2}{c}{ Double-hurdle Model } \\
\cline { 3 - 4 } & Model & Probit & $\begin{array}{c}\text { Truncated } \\
\text { Regression }\end{array}$ \\
\hline Lagged Seat Share & $0.65974^{* *}$ & 0.21560 & $0.33349^{*}$ \\
S1: GDP per Capita & $(0.14615)$ & $(0.13494)$ & $(0.13478)$ \\
S2: Urbanisation & $0.00012^{*}$ & 0.00005 & $0.00016 \dagger$ \\
& $(0.00006)$ & $(0.00006)$ & $(0.00008)$ \\
S3: Government Expenditure & $0.10463^{* *}$ & $0.05435^{* *}$ & 0.04488 \\
& $(0.01372)$ & $(0.01308)$ & $(0.04953)$ \\
P1: Policy space of New Politics issues & $0.07927^{*}$ & 0.01723 & -0.03595 \\
& $(0.04028)$ & $(0.02138)$ & $(0.05019)$ \\
P2: Party system divergence & $0.11352^{* *}$ & $0.10510^{* *}$ & -0.06899 \\
& $(0.02355)$ & $(0.03243)$ & $(0.04653)$ \\
I1: Threshold & 0.06439 & -0.01312 & 0.33919 \\
& $(0.12100)$ & $(0.04568)$ & $(0.23304)$ \\
I2: Electoral formulae & $-0.12834 \dagger$ & 0.00064 & $-0.59580^{* *}$ \\
& $(0.07253)$ & $(0.02146)$ & $(0.18505)$ \\
I3: Public party funding & 1.00707 & $1.00361^{*}$ & 0.22876 \\
& $(0.81043)$ & $(0.44737)$ & $(0.61708)$ \\
Constant & 0.09898 & 0.07091 & 0.28588 \\
& $(1.14839)$ & $(0.31761)$ & $(1.33026)$ \\
Observations & $-14.71697^{* *}$ & $-7.69584^{* *}$ & 1.79892 \\
Robust standard errors (clustered by countries) & in parentheses. & $* * \mathrm{p}<0.01, * \mathrm{p}<0.05, \dagger \mathrm{p}<0.1$ \\
Likelihood Ratio test of the double-hurdle model: $48.03>20.09(\mathrm{df}=8 ; \mathrm{p}<0.01)$. & \\
& $(2.00640)$ & $(2.08675)$ & $(6.11676)$ \\
& & & 76 \\
\hline
\end{tabular}


Appendix Table A4: Double-hurdle Model of ERPs (with a lagged seat share): Representation and Integration of New Politics issues

\begin{tabular}{|c|c|c|c|}
\hline \multirow[t]{2}{*}{ Dependent Variable: Seat share of ERPs } & \multirow{2}{*}{$\begin{array}{c}\text { Tobit } \\
\text { Model }\end{array}$} & \multicolumn{2}{|c|}{ Double-hurdle Model } \\
\hline & & Probit & $\begin{array}{l}\text { Truncated } \\
\text { Regression }\end{array}$ \\
\hline Lagged Seat Share & $\begin{array}{c}0.61389 * * \\
(0.16821)\end{array}$ & $\begin{array}{l}1.05598^{* *} \\
(0.19622)\end{array}$ & $\begin{array}{c}0.33454 \\
(0.26205)\end{array}$ \\
\hline S1: Foreigners & $\begin{array}{l}0.35437 \dagger \\
(0.20698)\end{array}$ & $\begin{array}{c}0.64630^{* *} \\
(0.23272)\end{array}$ & $\begin{array}{l}-0.12852 \\
(0.22182)\end{array}$ \\
\hline S2: Unemployment & $\begin{array}{c}0.31544 \\
(0.28395)\end{array}$ & $\begin{array}{l}0.73742^{*} \\
(0.28799)\end{array}$ & $\begin{array}{l}-0.23954 \\
(0.63177)\end{array}$ \\
\hline S3: Taxation & $\begin{array}{c}0.03822 \\
(0.00000)\end{array}$ & $\begin{array}{c}0.04554 \\
(0.06831)\end{array}$ & $\begin{array}{l}-0.28178 \\
(0.24652)\end{array}$ \\
\hline P1: Policy space of New Right issues & $\begin{array}{c}0.15378 \\
(0.00000)\end{array}$ & $\begin{array}{c}0.18111^{* *} \\
(0.03233)\end{array}$ & $\begin{array}{c}0.01689 \\
(0.07615)\end{array}$ \\
\hline P2: Party system divergence & $\begin{array}{r}-1.23323 \dagger \\
(0.68558)\end{array}$ & $\begin{array}{c}-0.71765 \dagger \\
(0.42036)\end{array}$ & $\begin{array}{l}-0.70961 \\
(0.93876)\end{array}$ \\
\hline I1: Threshold & $\begin{array}{l}-0.16569 \\
(0.13874)\end{array}$ & $\begin{array}{c}-0.19727^{* *} \\
(0.06203)\end{array}$ & $\begin{array}{l}-0.36466 \\
(0.43264)\end{array}$ \\
\hline I2: Electoral formulae & $\begin{array}{l}3.18117^{*} \\
(1.33280)\end{array}$ & $\begin{array}{c}3.14268^{* * *} \\
(1.04188)\end{array}$ & $\begin{array}{l}5.85834^{*} \\
(2.57622)\end{array}$ \\
\hline I3: Public party funding & $\begin{array}{l}2.42956 \dagger \\
(1.26017)\end{array}$ & $\begin{array}{c}0.14853 \\
(1.22565)\end{array}$ & $\begin{array}{c}6.18836^{* * *} \\
(2.28150)\end{array}$ \\
\hline Constant & $\begin{array}{l}-8.25021 \\
(6.87184)\end{array}$ & $\begin{array}{c}-12.86386^{* *} \\
(4.35161)\end{array}$ & $\begin{array}{c}5.62752 \\
(7.46799)\end{array}$ \\
\hline Observations & 75 & 75 & 48 \\
\hline
\end{tabular}

